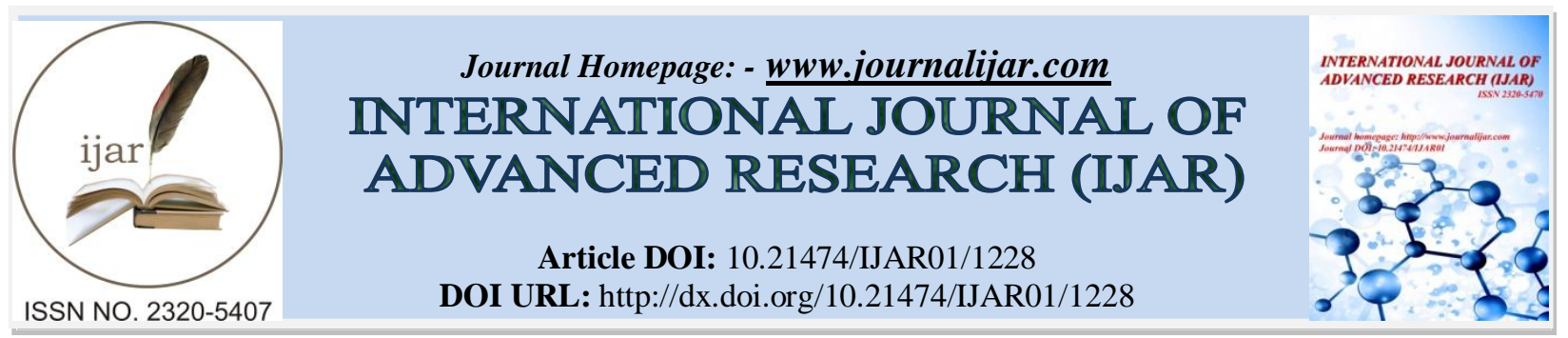

RESEARCH ARTICLE

\title{
IS GLYCINE SUPPLEMENTATION USEFUL IN CREATINE TRANSPORTER DEFICIENCY?
}

Jorge Sales Marques.

Metabolic Unit - Serviço de Pediatria do Centro Hospitalar Vila Nova de Gaia / Espinho EPE - Portugal.

\section{Manuscript Info}

Manuscript History

Received: 15 June 2016

Final Accepted: 20 July 2016

Published: August 2016

Key words:-

creatine transport deficiency, glycine, behaviour.

\begin{abstract}
Creatine transport defect (CT1) is a metabolic disorder with neurological symptoms. Glycine, a precursor, inhibit the neurotransmitters and has shown that improve memory retrieval loss and also has a sedative effect by reducing the excitability of nerves cells. The purpose of this study is treat with oral glycine (250 $\mathrm{mg} / \mathrm{kg} /$ day) in a period of 12 months, a patient with CT1 and compare the clinical, analytic and brain MRS evolution, before and after therapy. The results showed some improvement in concentration, socialization, perception and autonomy. The creatine peak was slightly better and urine creatine level reduces significantly.
\end{abstract}

Copy Right, IJAR, 2016,. All rights reserved.

\section{Introduction:-}

Creatine transport defect (CT1) is a x-linked disorder with neurological symptoms. Treatment with high doses of oral creatine did not result in any improvement in male affected with CT1.

The SLC6A8 gene is the marker of this disease.

Glycine stimulate creatine synthesis in creatine transporter 1-deficient lymphoblasts and also act as a creatine precursor.

Treatment with oral creatine, L-arginine and L-glycine in severely affected patients with creatine transporter defect, showed benefit only in the muscular symptoms of the disease. No improvement was found in the cognitive and psychiatric manifestations and did not modify brain creatine content on magnetic resonance spectroscopy (MRS). $(1-3)$

\section{Purpose:-}

Treat with oral glycine in the period of 12 months, a patient with CT1 and compare the clinical, analytic and brain MRS evolution, before and after therapy.

We stop glycine treatment during 3 months and evaluate the clinical evolution of the patient, (if he showed any regression of the symptoms) and urine creatine level. 


\section{Material:-}

A fourteen year-old boy with CT1 diagnosed at the age of eight years, treated unsuccessfully with daily $20 \mathrm{mg}$ of oral methylphenidate for is behaviors disturbances.

Method:-

Oral glycine in a dose of $250 \mathrm{mg} / \mathrm{kg} / \mathrm{day}$, divided in two doses.

\section{Results:-}

After 12 months, we found some improvement in concentration, socialization, perception and autonomy.

The concentration was much better in school and when doing homework's. The parents and teachers confirmed this evolution. The socialization was also improved and now he can stay in a place without moving from one side to another and can stay sit for minutes. The perception of fear was reduced and now he can walk in the street. The autonomy was better and he can take a bath by himself.

We cannot confirm any evolution of speech after introducing glycine in the treatment. Table1

Brain MRS after glycine showed thin corpus callosum that was detected before in the first MRS. - Figure 1

The creatine peak was slightly better than before (5 to $8 \mathrm{~mm})$. - Figure 2

Urine creatine level reduces from $24427 \mu \mathrm{mol} / \mathrm{mmol}$ creatinine at the diagnosis to 10994 (normal: 142 - 5952) Figure 3

After we stop glycine for 3 months, we found some regression of his behaviour, particularly in concentration and socialization (more distraction in contact eyes and cannot stay calmly in the seat, respectively).

The urine glycine increased from 10994 to $11987 \mu \mathrm{mol} / \mathrm{mmol}$ creatinine.

Table 1:-

\section{Behaviour evolution before and after oral Glycine}

\begin{tabular}{|l|c|c|c|c|c|c|c|}
\hline & Nothing & $\begin{array}{c}\text { Very } \\
\text { Poor }\end{array}$ & Poor & $\begin{array}{l}\text { Almost } \\
\text { Total }\end{array}$ & Total & Before & After \\
\hline Concentration & $\mathbf{1}$ & $\mathbf{2}$ & $\mathbf{3}$ & $\mathbf{4}$ & $\mathbf{5}$ & & \\
\hline Perception & & & & & & 1 & 3 \\
\hline Autonomy & & & & & & 1 & 3 \\
\hline Socialization & & & & & & 2 & 4 \\
\hline Speach & & & & & & 2 & 4 \\
\hline
\end{tabular}




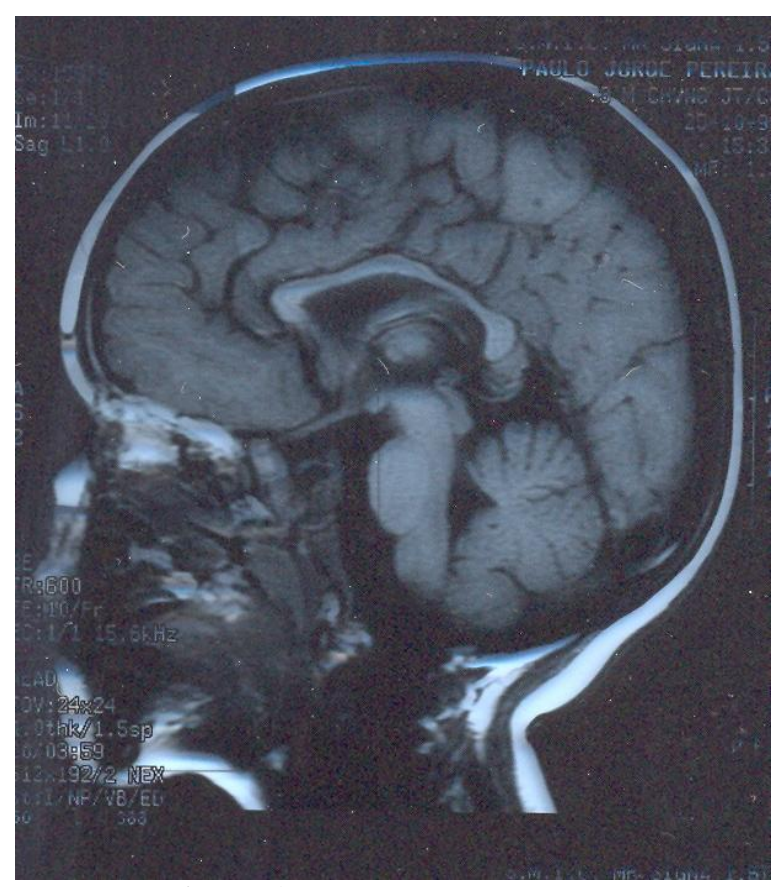

Figure 1:- Thin corpus callosun.

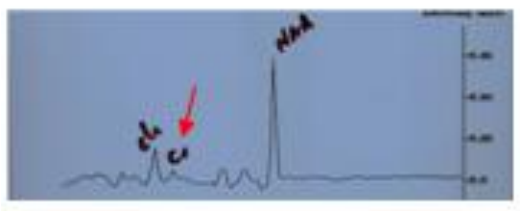

Before treatment $-0,5 \mathrm{~cm}$

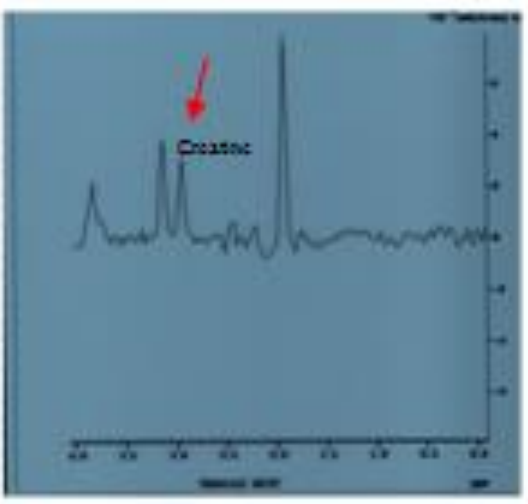

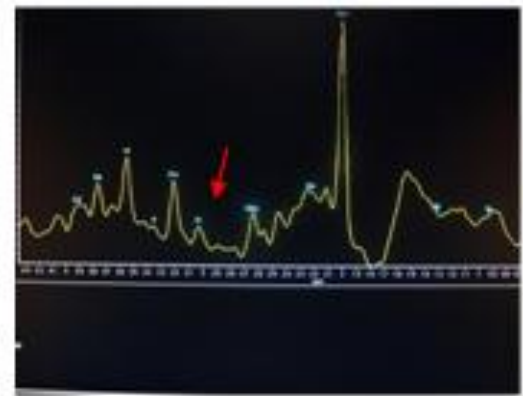

One year after glycine $-0,8 \mathrm{~cm}$

\section{Normal creatine level $-2,8 \mathrm{~cm}$}

Figure 2:- Brain creatine level. 


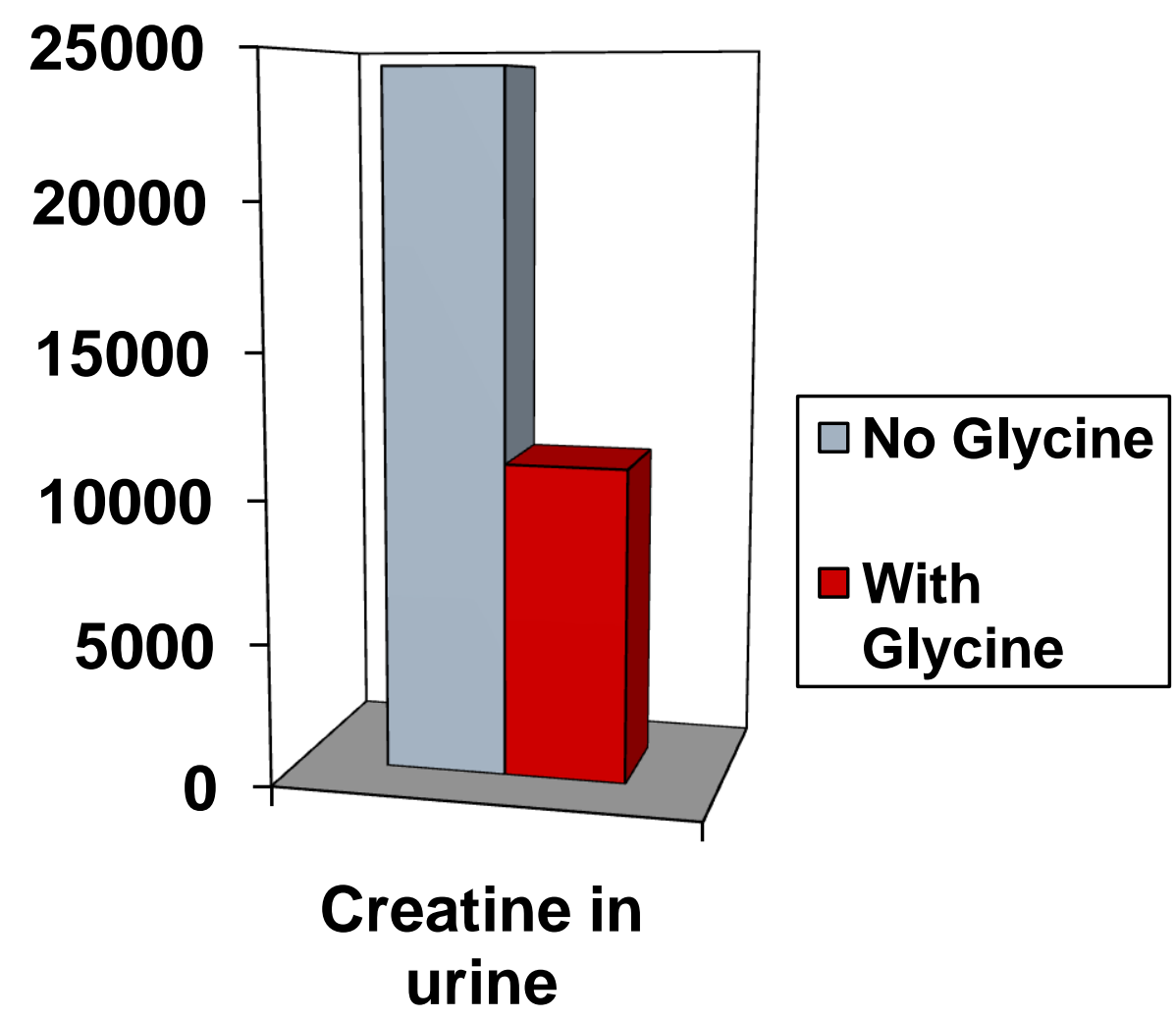

Figure 3:- Urine creatine level.

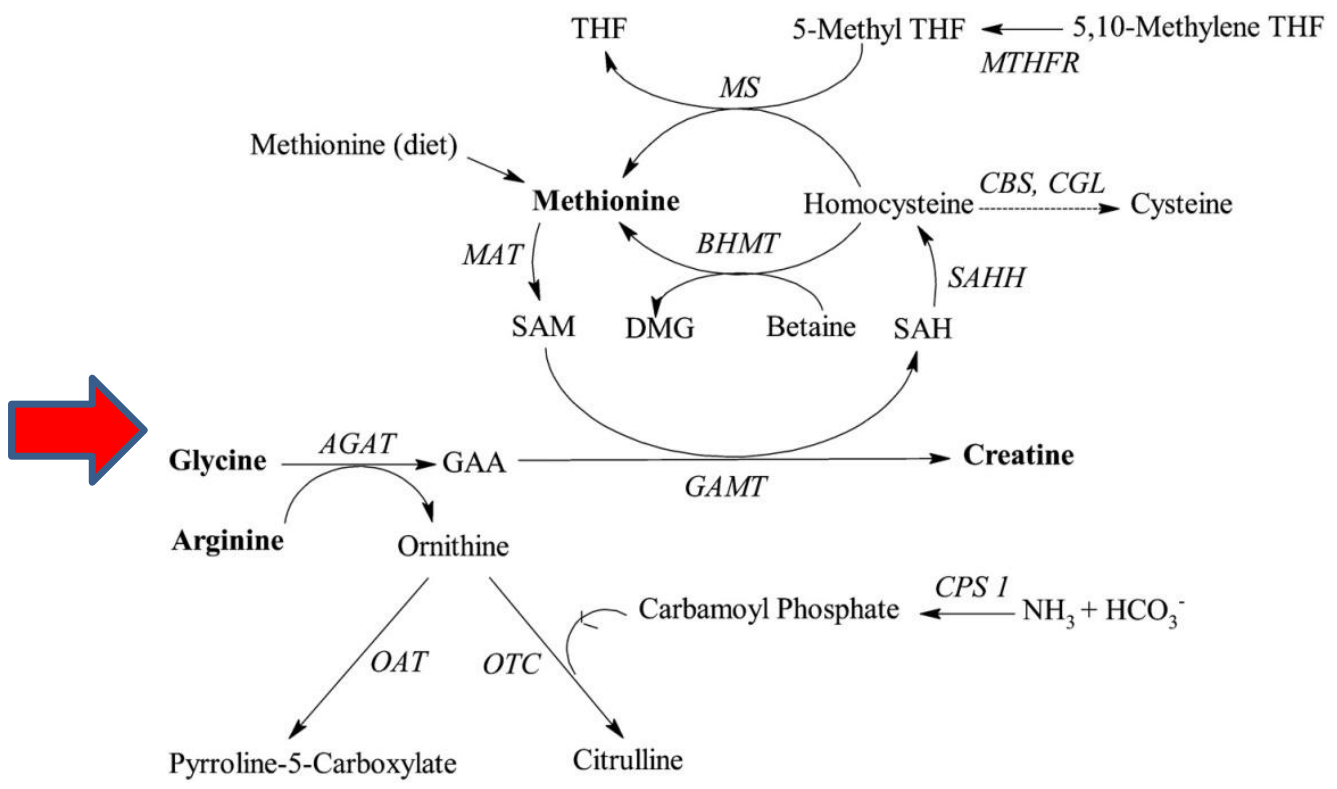

Figure 4:- glycine, a creatine precursor. 


\section{Discussion:-}

Our patient has a hemizygous missence mutation in SLC6A8 gene, with transversion of G to C (c.1261G>C) in exon 9 - substitution of glycine for arginine (p.Glic421Arg) - a novel mutation.

Clinically, he has mental retardation and behavioural changes. No epilepsy was found in his personal background.

We believe that the clinical and analytic evolution associated with increase creatine peak level was secondary to oral glycine, a creatine precursor.- Figure 4

Glycine, because of is inhibitory action over the neurotransmitters, in research studies has shown that helps improve memory retrieval loss in those patients that suffer from a wide variety of sleep-depriving conditions, including schizophrenia, Parkinson and Huntington diseases.

He also has a sedative effect and is used in attention-deficit, by reducing the excitability of nerves cells. $(2,3)$

There are been no toxic effects associated with glycine, although some people have reported stomach upset.

This symptom was not found in our patient.

When we stop the treatment for 3 months we found some regression is his behaviours and this can be explain by a small increase of urine creatine level.

\section{Conclusion:-}

Glycine seems useful in our case of CT1 defect, with some changes in the behaviour of the patient and should be considered in treatment of this neurometabolic disorder. .

\section{Reference:-}

1. Chilosi A, Leuzzi V, Battini R, Tosetti M, Ferretti G, Comparini A, Casarano M, Moretti E, Alessandri MG, Bianchi MC,Cioni G (2008). Treatment with L-arginine improves neuropsychological disorders in a child with creatine transport defect.

2. Neurocase, 14, 2: 151-161.

3. Leuzzi V, Alessandri MG, Casarano M, Battini R, Cioni G. (2008) Arginine and glycine stimulate creatine synthesis in creatine transporter 1-deficient lymphoblasts.

4. Anal Biochem, 375, 1: 153-155.

5. Valayannopoulos V et al. .(2012) Treatment by oral creatine, L-arginine and L-glycine in six severely affected patients with creatine transporter defect

6. J Inherit Metab Dis. 35, 1: 151-157. 